TEME, г. XLIII, бр. 3, јул - септембар 2019, стр. 901-923

Прегледни рад

Примљено: 28. 2. 2019.

https://doi.org/10.22190/TEME190228054M

Ревидирана верзија: 3. 6. 2019.

Одобрено за штампу: 20. 10. 2019.

\title{
THE EU COMMISSION'S PROPOSAL TO REVISE THE BRUSSELS IIa REGULATION: SHORTCOMINGS OF THE “OVERRIDING RULE" $a$
}

\author{
Sanja Marjanović \\ University of Niš, Faculty of Law, Niš, Serbia \\ sanjamarjan@yahoo.com
}

\begin{abstract}
As the procedure for the revision of the Brussels IIa Regulation is currently pending in the European Union, this paper focuses on the two issues which are correlated through the so-called "overriding rule" mechanism. The first problem concerns the proceeding on the return of the wrongfully removed or retained child involving two EU Member States - the State of refuge and the State where the child was habitually resident immediately before the abduction. The second one tackles the proceeding, currently regulated in the Brussels IIa, on the rights of custody (parental responsibility) when the return of the child was refused in the EU State on the grounds of Art. 13 of the Hague Child Abduction Convention. The proposals for the revision of the Brussels IIa Regulation heavily involve these issues. In that respect, the author indicates certain shortcomings and inconsistencies of the amendments proposed by the European Commission in the Proposal to Revise the Brussels IIa Regulation (2016) and the latest compromise solutions suggested by the Presidency to the Council in the General Approach to the Recast of Brussels IIa (2018). At the same time, the paper suggests two possible ways in which the balance between the principle of mutual trust between the EU Member States and the principle of the child's best interest could be better balanced. From the perspective of Private International Law of the Republic of Serbia, the revision of the Brussels IIa Regulation is important in view of Serbia's candidate status for EU membership and the need to keep an eye on changes to the secondary EU legislation.
\end{abstract}

Key words: Brussels IIa Regulation, the 2016 EU Commission's Proposal to Revise the Brussels IIa Regulation, the 2018 General Approach of the Presidency on the Revision of the Brussels IIa Regulation, "overriding rule", "privileged" decisions.

\footnotetext{
${ }^{a}$ This paper is a result of the research conducted within the Faculty of Law University of Niš's project „Protection of Human and Minority Rights in the European Legal Area” financed by the Ministry of Education, Science and Technological Development of the Republic of Serbia (number 179046 D).
} 


\title{
ПРЕДЛОГ ИЗМЕНА УРЕДБЕ БРИСЕЛ НА: НЕДОСТАЦИ ТЗВ. ПРЕОВЛАБУЈУЋЕГ ПРАВИЛА
}

\begin{abstract}
Апстракт
Имајући у виду да је у Европској унији у току поступак за измену Уредбе Брисел IIa, у овом раду се разматрају два питања, међусобно повезана тзв. правилом о примату. Први проблем тиче се поступка за повратак незаконито одведеног или задржаног детета који укључује две државе Европске униje - државу уточишта и државу у којој је дете имало уобичајено боравиште непосредно пре отмице. У другом случају, реч је о одредбама Уредбе о поступку мериторног одлучивања о праву на старање (родитељској одговорности) након што је повратак детета одбијен у држави Уније на основу члана 13 Хашке конвенције о грађанскоправним аспектима међународне отмиие деце. Најављене измене Уредбе Брисел II во ова питања. С тим у вези, аутор истиче одређене недостатке и недоследности одредаба из Предлога Европске комисије о изменама Уредбе (2016), као и најновијих, компромисних решења, које је Председништво упутило Савету у Опитем приступу изменама Уредбе (2018). Истовремено, у раду се сугеришу два начина на које би се евентуално могао постићи уједначенији однос између принципа међусобног поверења држава ЕУ и принципа најбољег интереса детета. Из угла међународног приватног права Репубике Србије, измене Регулативе Брисел IIa важне су имајући у виду статус наше државе као кандидата за чланство у Европској унији и потребу праћења измена секундарног законодавства ЕУ.
\end{abstract}

Кључне речи: Уредба Брисел ІІа, Предлог Европске комисије за измене Уредбе Брисел ІІа (2016), Општи приступ Председништва изменама Уредбе Брисел Брисел ІІа (2018), ,преовлађујуће правило”, „привилеговане” одлуке.

\section{INTRODUCTION}

The Brussels IIa Regulation regulates the jurisdiction, recognition and enforcement of decisions in the matters of divorce, marriage annulment and legal separation, as well as parental responsibility. ${ }^{1}$ It is considered to be the "cornerstone of judicial cooperation in family matters in the European Union" (European Commission, 2016, p. 2). Nevertheless, the decade of its practical application has raised several important concerns which have been heavily discussed in the private international law theory, especially in terms of parental responsibility and child abduction cases. ${ }^{2}$ These provisions could

\footnotetext{
${ }^{1}$ Council Regulation (EC) No 2201/2003 of 27 November 2003 concerning jurisdiction and the recognition and enforcement of judgments in matrimonial matters and the matters of parental responsibility, repealing Regulation (EC) No 1347/2000, OJ L 338. 23.12.2003. ${ }^{2}$ See especially, Dutta, Schulz, 2014, pp. 1-40; Beaumont, Walker, Holliday, 2016, pp. 211-260; Kruger, Samyn, 2016, pp. 132-168; Dutta, 2016, pp. 169-184; Ubertazzi, 2017, pp. $568-601$.
} 
be described as the weakest point in the otherwise reasonably strong chain of the Brussels IIa rules. The core of the problem is the fact that the Brussels IIa Regulation upgrades the mechanism already set in the 1980 Hague Convention on the Civil Aspects of International Child Abduction (the 1980 Hague Convention), ${ }^{3}$ concurrently trying to reconcile the rights of custody, the best interest of the child, and the principle of mutual trust between the EU States. ${ }^{4}$ Therefore, in terms of the return proceedings and the subsequent proceedings on the rights of custody, ${ }^{5}$ the Brussels IIa Regulation takes precedence over the 1980 Hague Convention in relations implying two EU Member States, as clarified in Article 60 (1) point e) of the Brussels II a. In other aspects, the Hague Convention still applies unaltered. ${ }^{6}$

On $30^{\text {th }}$ June 2016, the European Commission submitted the Proposal for recasting the Brussels IIa Regulation (the 2016 Proposal). ${ }^{7}$ On $30^{\text {th }}$ November 2018, the Presidency submitted the General Approach on the Brussels IIa Recast, ${ }^{8}$ as a compromise proposal with the aim of reaching an agreement among all Member States. ${ }^{9}$ On $7^{\text {th }}$ December 2018,

${ }^{3}$ Convention of 25 October 1980 on the Civil Aspects of International Child Abduction.

${ }^{4}$ For the CJEU case law on the principle of mutual trust see especially Prechal, 2017, 75-92. This principle was also acknowledged by the European Commission itself, which has emphasized the following shortcomings in the context of child abduction cases: the different interpretation of the six-weeks time limit among different jurisdictions; no time limits for processing of an application by the Central Authority; non-unified number of appeals available in national law systems; lack of specialization of the courts and the so called „overriding rule" mechanism. European Commission, 2016, p. 3.

${ }^{5}$ Article 11 of the Brussels IIa Regulation.

${ }^{6}$ See in detail, Lazić, 2018, 134.

7 European Commission, Proposal for a Council Regulation on jurisdiction, the recognition and enforcement of decisions in matrimonial matters and the matters of

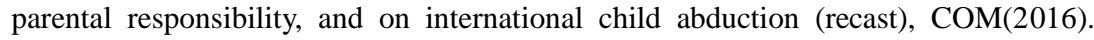
30.6.2016 411, final 2016/0190 (CNS).

${ }^{8}$ Presidency to the Council, Proposal for a Council Regulation on jurisdiction, the recognition and enforcement of decisions in matrimonial matters and the matters of parental responsibility, and on international child abduction (recast) - General approach, 14784/18. JUSTCIV 292.

${ }^{9}$ As the Presidency stated in the 2018 General Approach "Bearing in mind the unanimity requirement and the principle that nothing is agreed until everything is agreed, the Presidency is submitting this compromise proposal to the Council with the aim of achieving an agreement among all Member States. The elements of the compromise text are to be seen as an overall package that aims at establishing new rules which are simpler and more efficient to use for the children and their families as well as for practitioners. The compromise also provides for a delicate balance between different positions of Member States, while at the same time fostering mutual trust among them." (Presidency, 2018, p. 3). These compromise includes the following ideas: the complete abolition of exequatur; a limitation of jurisdiction for provisional measures to States where the child or property belonging to the child is present; allowing the cross-border recognition and enforcement of provisional measures 
the Council of the European Union approved the General Approach ${ }^{10}$ and it is expected that the Brussels IIa Recast Regulation will be enacted in the following months.

This paper focuses on the provisions of the "overriding rule" regarding the child abduction cases and parental responsibility, as amended in the 2016 Proposal and the 2018 General Approach. In that regard, it should be emphasized that the relevant provisions of the Brussels IIa Regulation Recast are applicable where a child has been wrongfully removed to, or is being wrongfully retained in a Member State other than the Member State where the child was habitually resident immediately before the wrongful removal or retention (Art. 74 of the 2016 Proposal). In contrast, the 1980 Hague Convention remains unaltered in the child abduction cases involving third States. ${ }^{11}$ Although the new proposals include commendable improvements of the current Brussels IIa mechanism in the child abduction cases, there are two notable shortcomings. The first one relates to the enhancement of time-limits for deciding on the return of the child where, at the same time, there is a lack of time-limits with regard to the proceedings on the substance of rights of custody (parental responsibility) following the refusal of the return of the child on certain grounds of Art. 13 of the 1980 Hague Convention. ${ }^{12}$ The second inconsistency tackles the possibility to stay or refuse the direct enforcement of the so called "privileged" decisions entailing the return of the child which are rendered in the abovementioned proceedings on the substance of rights of custody. Finally, some closing remarks and suggestions have been made.

granted by the court to where the child has been abducted when ordering the return; the harmonization of certain rules on actual enforcement; making the time frame for return proceedings and their enforcement more stringent; providing for the hearing of children; clearer rules on the placement of children; clearer rules on the circulation of extra-judicial agreements. Presidency, 2018, pp. 4-9.

${ }^{10}$ Council of the EU, Council agrees on more effective rules to solve cross border parental responsibility issues, 2018.https://www.consilium.europa.eu/en/press/pressreleases/2018/12/07/council-agrees-on-more-effective-rules-to-solve-cross-borderparental-responsibility-issues/pdf.

${ }^{11}$ Lazić, 2018, 134.

${ }^{12}$ In general, Art. 13 of the 1980 Hague Convention prescribes three grounds for refusing the return of the child: 1 ) the person, institution or other body having the care of the person of the child was not actually exercising the custody rights at the time of removal or retention, or had consented to or subsequently acquiesced in the removal or retention; 2) there is a grave risk that his or her return would expose the child to physical or psychological harm or otherwise place the child in an intolerable situation; 3 ) the child objects to being returned and has attained an age and degree of maturity at which it is appropriate to take account of its views. 


\section{THE OVERRIDING RULE MECHANISM}

The current Brussels IIa Regulation has introduced the overriding rule mechanism which enables the court in the State in which the child was habitually resident immediately before the wrongful removal or retention to decide on the rights of custody (parental responsibility). The retention of jurisdiction comes to the fore if the court of the State in which the child was wrongfully removed or retained (State of refuge) has refused the return of the child on any ground envisaged in Art. 13 of the 1980 Hague Abduction Convention. ${ }^{13}$ The decision rendered in the State of the child's habitual residence entailing the return of the child is concerned to be the "privileged" one since there is no possibility of opposing its recognition if the judgment has been certified in the Member State of origin. In addition, the "privileged" decisions are enforceable without the need for a declaration of enforceability, while the direct enforcement could be refused only if the decision is irreconcilable with a subsequent enforceable judgment (Brussels IIa Regulation, 2003, Arts. 42 and 47). Therefore, the overriding rule mechanism enables the court in the State of the child's habitual residence to have a final word on the return (Dutta et al., 2014, p. 22). The ratio of this mechanism is to make stronger deterrent effect on the abducting parent, but its practical application has proven to be difficult, bearing in mind that the child is not present in the State where the proceeding on the rights of custody takes place. ${ }^{14}$ Thus, this mechanism is a controversial issue (Dutta et al., 2014, p. 21). Therefore, the 2016 Proposal and the 2018 General Approach are aimed at improving the overriding rule.

\section{Notion of the "Privileged" Decisions Entailing the Return of the Child}

The Brussels IIa Regulation authorizes the court in the State of the child's habitual residence to issue any subsequent judgment which requires the return of the child following the non-return decision in the State of refuge (Brussels IIa, 2003, Article 11 para. 8). According to the leading EU Court of Justice (CJEU) rulings, the rather broad interpretation of this provision has to be upheld. ${ }^{15}$ Hence, in the current Brussels IIa system, the term "any subsequent judgment requiring the return of the child" implies even the decision on the mere return, regardless of the judgment on the merits of parental responsibility (Dutta et al., 2014, p. 24). In that respect, a provisional measure could also be the ground for the return of the child. Moreover, both of these decisions, followed by the certificate, are qualified to be "privileged", enabling the direct enforcement without any possibility

\footnotetext{
${ }^{13}$ Brussels IIa Regulation, 2003, Art. 11 paras. 6-8 in conjunction with Art. 10.

${ }^{14}$ EU Commission, 2016, p. 3. See also Beaumont et al., 2016, p. 224.

${ }^{15}$ See especially CJEU decision in the Case C-211/10 PPU (Povse v. Alpago) (2010] ECR I-6669.
} 
for a refusal of the recognition. ${ }^{16}$ In terms of the decisions on the mere return and the provisional measures on custody, the fact that the court in the State of the child's habitual residence prior to the wrongful removal or retention usually lacks the direct insight into the current state of affairs regarding the child and the fact that it brings these decisions in the summary proceeding have raised serious concerns. ${ }^{17}$

On the other hand, the 2016 Proposal specifies that the decisions entailing the return of the child (in terms of the overriding mechanism) are the decisions on the question on custody (Art. 26. para 4). This notion excludes decisions on the mere return, but it seems unclear whether it could still leave the door ajar for the interim measures on custody which are rendered in the course of custody proceedings. A different solution has been adopted in the 2018 General Approach, which implies a more precise term decision on the substance of rights of custody (Art. 26, para. 6(a)). In order to prevent any misinterpretation, the Presidency has emphasized in the new recital that "this mechanism should be limited to decisions on the substance of rights of custody". ${ }^{18}$ Consequently, only the decisions on the merits could serve as a legal ground for the return of the child. Although this new provision on the notion of the "privileged" decision is much needed, the effectiveness of some other proposed amendments may be subject to further discussion. ${ }^{19}$

\section{Proceedings on the Substance of Rights of Custody Following the Refusal of the Return}

Another issue regarding the Brussels IIa overriding mechanism is related to the proceeding on the substance of rights of custody following the refusal of the return of the child. The 2016 Proposal relies in its Art. 26 para. 2 on the current Brussels IIa Regulation ${ }^{20}$ by envisaging the application of the overriding mechanism in any case when the return was refused on at least one ground specified in Article 13 of the 1980 Hague Convention. As already mentioned, these rules of the EU secondary legislation are applicable only in the relations between the EU Member States. ${ }^{21}$

However, the 2018 General Approach in Art. 26a sets the same mechanism in motion only when the refusal is based solely on one of the two specified grounds of Art. 13 of the 1980 Hague Convention. The first

\footnotetext{
${ }^{16}$ Brussels IIa Regulation, 2003, Art. 40 para. 1.

${ }^{17}$ See e.g. ECtHR decision on the violation of Art. 8 of the European Convention in one of the landmark case Šneersone and Kampanella $v$ Italy, Application No 14737/09 (ECtHR decision of 12.06.2011).

${ }^{18}$ Presidency, 2018, p. 45 (new recital).

${ }^{19}$ Also, Lazić, 2018, 10.

${ }^{20}$ Brussels IIa Regulation, 2003, Art. 11 para. 6

${ }^{21}$ See supra ft. 6.
} 
one relates to the grave risk exception, envisaged in point b) of Art. 13 (1) of the 1980 Hague Convention. ${ }^{22}$ The second one is the view of the child, as envisaged in Art. 13 para. 2 of the 1980 Hague Convention. ${ }^{23}$ Although not anticipated, the results of the studies conducted within the EU Member States have shown that the decisions on refusal rendered only on the grave risk exception prevail. ${ }^{24}$ Hence, the new approach taken by the Presidency is a reasonably balanced solution which directly makes the overriding rule applicable only to the refusal of the return on the grave risk exception or the view of the child.

\section{The Issue of Time Limits}

As the current Brussels IIa Regulation sets out, the proceeding on the child's return to the State of his/her habitual residence is urgent and the judge should render the decision no later than six weeks after the application for the return of the child is lodged (Brussels IIa Regulation, 2003, Art. 11, para. 3). This solution is taken from Art. 11 para. 2 of the 1980 Hague Convention. The only difference is that the Brussels IIa implies the court's duty to respect the time limit in a more rigid manner. ${ }^{25}$ Nevertheless, the delays, even in the EU States, were inevitable in practice, at different stages of procedure, making the average duration of the return proceedings up to 165 days in contrast to the envisaged 42 days (six weeks) time limit. ${ }^{26}$

In that regard, a shift has been made with the 2016 Proposal, which calls for more stringent provisions. Hence, the six-week time limit is evenly applicable at the first instance proceedings and at the appellate court, including the processing of the application by the Central Authorities as well as their other duties, respectively (European Commission, 2016, p. 13). ${ }^{27}$

\footnotetext{
${ }^{22}$ In terms of Art. 13 para. 1 point b) of the 1980 Hague Convention, the ground for the refusal of the return is a grave risk that his or her return would expose the child to physical or psychological harm or otherwise place the child in an intolerable situation (grave risk exception).

${ }^{23}$ Art. 13 para. 2 of the 1980 Hague Convention envisages that the judicial or administrative authority may also refuse to order the return of the child if it finds that the child objects to being returned and has attained an age and degree of maturity at which it is appropriate to take account of his/her views.

${ }^{24}$ The last research has indicated that in $50 \%$ of the cases of the overriding rule, the return of the child was refused on the grave risk exception (Art. 13(1) point b) of the 1980 Hague Convention), while in further seven cases the grave risk exception was combined with other grounds set in Art. 13 (in five cases, it was combined with the child's view and in two cases with point a) of Art. 13(1)). On the other hand, the child's view was the sole ground in only $14 \%$ of the cases. Beaumont et al., 2016, pp. 215-216.

${ }^{25}$ Compare the wording of Art. 11 para. 2 of the 1980 Hague Convention and Art. 11 para. 3 of the Brussels IIa.

${ }^{26}$ Permanent Bureau, 2011, p. 10-12. Presidency, 2018, p. 11.

${ }^{27}$ For the purpose of this paper, we will refer to this timeframe as the , $6+6+6$ formula".
} 
This " $6+6+6$ formula" could be circumvented only due to the exceptional circumstances of a case. This possibility is expressly envisaged in the relevant provisions for the first instance proceeding and the duties of the Central Authorities (Art. 23 para. 1 and Art. 63 para 1(g). On the other hand, it is not expressly envisaged in a special provision for the proceeding on the appeal, but rather in the new recital. ${ }^{28}$ In terms of the appeal, the 2016 Proposal directly intervenes with the national rules of the Member States on the available legal recourses, stipulating that only one appeal should be permitted (Art. 25 para. 4). The rationale is the fact that the appeal proceedings could also cause delays in deciding on the rights of custody, even when a first instance court renders a decision in the six-week timeframe (Drventić, 2017, p. 439). In that respect, the provision on the limited number of appeals is justified, but the possibility to prolong the six-week time limit in the exceptional cases at the appellate court should be expressly envisaged in that same provision rather than in the recital. Although the newly proposed provision on the time-limits are legally binding only for the EU States, it should be noted that they could serve as a model for the non-member States as well, especially those who have obtained the status of the EU candidate State (Serbia, Republic of North Macedonia, Montenegro, Turkey and Albania).

The other interference of the 2016 Proposal with the national legal systems of the Member States, which is correlated with the issue of timelimits, concerns the proposed concentration of jurisdiction within the limited number of courts in a Member State (Art. 22). The ratio for this concentration is to make the proceedings for the return of the child more expedient. The judges specialized in settling the cases of wrongful removal or retention of the child should be able to conduct the proceedings in a more proficient and efficient manner. ${ }^{29}$ In other words, the urge to handle the cases on the child's return expeditiously and the urge to render the decision in compliance with the best interest of the child in concreto could be reconciled by the concentration of jurisdiction (Župan, Poretti, 2015, pp. 346-350).

In comparison to the 2016 Proposal, the 2018 General Approach keeps the same timeframe but it expressly prescribes in the separate provision the possibility for the appellate court to exceed the time-limit (Art. 23 para. 3 ). However, the provision on the limited number of appeal is omitted, as well as the one on the concentration of local jurisdiction. Still, the 2018 General Approach suggests in the new recitals that the Member States should consider both of these issue.$^{30}$ In that respect, the proposed amendments in the 2016 Proposal seem to be more efficient, although more demanding for

\footnotetext{
${ }^{28}$ European Commission, 2016, p. 25 (recital 26).

${ }^{29}$ European Commission, 2016, p. 3.

${ }^{30}$ Presidency, 2018, pp. 38-39 (recitals 25 and 26).
} 
the national legal systems of the EU States. It should be emphasized that the procedure for the adoption of the Brussels IIa recast is not finished, so the doors for the modifications are still open.

In terms of the return proceedings, the most of the novelties should be regarded as crucial improvements in comparison with the system established by the current Brussels IIa regime. However, when it comes to the issue of time-limits, it may appear reasonable not to rush with the overall conclusion. Regardless the fact that the 2016 Proposal and the 2018 General Approach prescribes different grounds for setting in motion the overriding rule mechanism, the problem of time-limits is common. In that respect, the overriding rule comes to the fore in case of refusal of the child's return in terms of any ground referred to in Art. 13 (the 2016 Proposal) or only in the case of the grave risk exception or the view of the child, which are the most delicate to handle (the 2018 General Approach). Let us consider the typical scenario in which the grave risk exception leads to the refusal of the return. This ground is common for the 2016 Proposal and the 2018 General Approach and, at the same, it is the most frequently raised in the EU States. ${ }^{31}$ In the ideal timeframe scenario, the first instance court renders the decision on the non-return of the child within the period of six weeks after the application is lodged. The left-behind parent submits an appeal and the appellate court refuses the appeal adhering to the six-week time-limit. In this ideal hypothetical case, all the involved authorities have observed the time-limits, which still brings us to the fact that the child, who has been artificially uprooted from the State of his/her habitual residence, has already lived in the State of refuge for at least 3 months (12 weeks). ${ }^{32}$

Then, the overriding rule comes into play. In the case where the court in the State of the child's habitual residence has already been seized to decide on the substance of rights of custody, the court which refused the return has to transmit the list of the documents to the court examining the merits of the case within one month of the date of the non-return decision (the 2018 General Approach, Art. 26a para. 3). ${ }^{33}$ According to the 2016

\footnotetext{
${ }^{31}$ See supra ft. 24.

32 This implies that the Central Authorities have performed their tasks in the six-week timeframe. Nevertheless, it should be emphasized that other circumstances could prolong the period in which the child lives in the State of refuge, such as: hesitations of the left-behind parent to lodge the application hoping that the taking parent will eventually return with the child; in the most common cases of the retention of the child, it usually takes time for a left-behind parent to realize that the child has been wrongfully retained; the problems in discovering the whereabouts of the child, etc.

${ }^{33}$ According to Art. 26a para. 3 of the 2018 General Approach, this duty applies only if the court in the State of refuge is aware of the proceeding on the substance of the parental responsibility (which will probably be the case as the party will inform the court during the proceeding on the return). Beside the certificate, the list of documents includes a copy of the decision, as well as a transcript, summary or minutes of the hearings before the court,
} 
Proposal this duty applies regardless whether the proceeding on the substance of the rights of custody has already been initiated (Art. 26 para. 2).$^{34}$ If the proceeding on the merits has not yet been initiated, the parties have to bring the lawsuit on the rights of custody within three months of the notification of a decision on the refusal of return (the 2018 General Approach, Art. 26a para. 5 ) or within three months of the notification from the court which received the decision and the documents (the 2016 Proposal, Art. 26 para. 3). Although the 2016 Proposal and the 2018 General Approach prescribe different moment from which the same three months' time limit applies, if we take another look at our ideal hypothetical scenario, it means that in both cases the child could spend at least six months in the State of refuge before the action on the substance of rights of custody has been lodged in the State of the child's habitual residence. ${ }^{35}$

This brings us to the crucial problem of the lack of time-limits in terms of the proceeding on the substance of rights of custody which could result in the "privileged" decision. The proceedings on parental responsibility brought by the action are, as a rule, time-consuming. This fact is even more apparent in child abduction cases, not only because the court has to make indepth examination of the best interest of the child who is not present in the forum State but also because the harsh battle between parents reaches its peak. This is even more evident in the overriding rule cases. ${ }^{36}$ The court in the State of the child's habitual residence has to take full evidence on the best interest of the child in order to assess which parent the child will live with, including the reasoning of the non-return decision in the State of refuge. Therefore, the lack of the reasonable time limits for the proceeding on the substance of rights of custody in the cases following the non-return orders could reverse the goal of the time limits set for the return proceeding. ${ }^{37}$

and any other documents it considers relevant. The documents can be forwarded either directly or through the Central Authorities.

${ }^{34}$ There is a modification of the current provision on the one-month time-limit in the Brussels IIa Regulation. Although the deadline appears to be the same, the 2016 Proposal and the 2018 General Approach provides that the court in the State of refuge has to transmit the documents to the court seized on the merits of the case within one month of the date of the non-return order (Art. 26 para. 2 of the 2016 Proposal and Art. 26a para. 3 of the 2018 General Approach), while the Brussels IIa states that the court shall receive all the mentioned documents within one month of the date of the non-return order. (Art. 11 para. 6). Therefore, the time limit in the Brussels IIa is slightly shorter than the one in the 2016 Proposal or in the 2018 General Approach.

${ }_{35}$ Counting 12 weeks' time limit for the return proceeding and 3 months' time limit for instituting the proceeding on the merits.

${ }^{36}$ Beaumont et al., 2016, p. 258.

${ }^{37}$ The author of this article raised the problem of the lack of time-limits during the round-table discussion at the $14^{\text {th }}$ Regional PIL Conference „Private International Law Revisited: Is there room for improving the existing PIL sources?”, organized by Prof. Ines Medic and held at the Law Faculty in Split (Croatia) on $3^{\text {rd }}$ November 2017, It 
It should be borne to mind that the ratio of the time-limits for the return proceedings is to re-established, as soon as possible, the bonds which were artificially adjourned (by the act of wrongful removal or retention) between the child, the left-behind parent, and the environment in which the child was settled. However, the proceeding on the return is only half way through. The other half way through is the proceeding on the substance of rights of custody. As it is expressly stated in the 2016 Proposal, in child abduction cases "timing is key to the successful operation of the return procedure". ${ }^{38}$ This conclusion was confirmed by the CJEU, reasoning that the cases involving the right of custody are urgent (Lenaerts, 2013, p. 1303). The fact that the overriding mechanism gives "a final word on the return" to the decision on the substance of rights of custody ${ }^{39}$ means that conflict between the non-return order and the subsequent return order adopted by the court of origin has to be resolved in favor of the subsequent one "in order to secure the return of the child". ${ }^{40}$ Therefore, the issue of time-limits for the subsequent proceeding which could result in the "privileged" decision has to be taken into consideration. One may purport that setting the time-limits in terms of the proceedings on the substance of rights of custody could jeopardize the in-depth assessment of the best interest of the child. Conversely, it may be argued that one part of the evidence is already easily accessible - in the documents related to the proceeding in the State of refuge, which has to be taken into account in the proceeding on the merits.

Yet, if there are no time limits at all, the child in our hypothetical scenario could continue to live in the State of refuge for almost a year (or more) before the decision on the merits is rendered. It should be kept in mind that the children of the young age easily adapt to the new environment and their perception of time is rather different. ${ }^{41}$ In case of the decision entailing the return of the child, if the child has lived in the State of refuge for a year or more waiting for the outcome of the proceedings on the

should be emphasized that some EU PIL professors also raised their voices on this problem. See: Kruger et al., 2016, pp. 159, 161; Beaumont et al., 2016, pp. 225-226, ft. 72. However, the EU Commission (in the 2016 Proposal) as well as the Presidency (in the 2018 General Approach) have remained silent on this issue, even in the newly proposed recitals.

${ }^{38}$ The EU Commission, 2016, p. 3.

${ }^{39}$ Dutta et al., 2014, p. 22

${ }^{40}$ European Commission, 2014, p. 13.

${ }^{41}$ The ECtHR has taken a similar position stating that the return of the child requires urgent handling as the passage of time can have the irremediable consequences. Shaw $v$ Hungary (application no. 6457/09), Raw v France (application no. 10131/11). See also: European Commission, 2014, p. 15. On the contradiction between the best interest of the child and the mutual trust between EU States in the case Raw v France, Marjanović, 2015, p. 883-886. 
substance of rights of custody, could we still claim without any doubt that the decision will restore the status quo ante?

Furthermore, if the Brussels IIa recast must enhance the mutual trust between national courts, interpreted in light of the legal certainty principle, ${ }^{42}$ does it mean that in the child abduction cases only the courts in the State of refuge should be expressly obliged to completely trust the courts in the State of the child's habitual residence and not vice versa? This can easily become circulos vitiosus which demonstrates the lack of trust with the courts of the State of refuge, particularly given that the proposed amendments in the 2016 Proposal and the 2018 General Approach insist on imposing the time-limits for deciding on the return at all instances. The 2016 Proposal goes even further expressly prescribing the restriction of the number of appeals, and the concentration of local jurisdiction (which are all well justified proposals). Still, there is readiness to express full trust in the efficiency of the judicial system of that same Member State when it is not the State of refuge but rather the State where the child was habitually resident immediately before the wrongful removal or retention. The trust is set so high that the decisions entailing the return of the child rendered by the courts of that State are considered as "privileged". ${ }^{43}$ Moreover, if the final intention of the Brussels IIa recast would be the introduction of the judicial specialization by concentrating the local jurisdiction for child abduction cases, then it should be emphasized that the decisions on the substance of rights of custody could be still rendered by the courts which usually decide on parental responsibility regardless of its national or a cross-border element. So, the time-limits have to be defined in order to fully implement the principles of mutual trust and the best interest of the child.

\section{THE ENFORCEMENT OF THE DECISIONS ON THE RIGHTS OF CUSTODY}

Under the Brussels IIa regime, the recognition and enforcement of the decisions on the rights of custody rendered by the court in the other Member State of the child's habitual residence entailing the return of the child is almost guaranteed. ${ }^{44}$ In that respect, this type of decisions shall be recognised

\footnotetext{
${ }^{42}$ Lenaerts, 2013, p. 1304.

${ }^{43}$ Art. 38 para. 2 of the 2016 Proposal; Art. 47 para. 1(b) and Art. 47n of the 2018 General Approach.

${ }^{44}$ On the other hand, the decisions on the substance of the rights of custody rendered in the EU State in which the child was habitually resident immediately before the removal or retention are not automatically recognized or enforced when the State of refuge is the third State (non EU Member State). In this case, the recognition and enforcement of the decision on the merits entailing the return of the child are governed by other international conventions (depending on the circumstances, it could be a bilateral or a multilateral convention, e. g. the Hague Convention of 19 October
} 
without any possibility of opposing its recognition if the judgment has been certified in the Member State of origin (the Brussels IIa Regulation, 2003, Art. 42 para. 1). ${ }^{45}$ When it comes to the enforcement of this decision, it will be enforceable in other Member States without the need for a declaration of enforceability if it is enforceable in the State of origin (the Brussels IIa Regulation, 2003, Art. 42 para. 1). The only ground for the refusal of enforcement is its irreconcilability with a subsequent enforceable judgment (the Brussels IIa Regulation, 2003, Art. 47 para. 2). This rigorous approach leaves no room for the competent authority in the Member State of enforcement to react. This includes even the cases of subsequent change of circumstances ${ }^{46}$ when the enforcement would seriously detriment the best interest of the child and infringe the Charter of Fundamental Rights. ${ }^{47}$

\section{The 2016 Proposal - General Rule and Exceptional Cases}

The 2016 Proposal envisages, to a certain extent, a different approach. Regarding the recognition, the decision on the rights of custody entailing the return of the child could be challenged if it is irreconcilable with the later decision on the same issue given in the Member State in which recognition is sought, or in another Member State, or in the non-Member State of the habitual residence of the child provided that the later decision fulfils the conditions necessary for its recognition in the Member State in which recognition is sought (Art. 38 para. 1 (d) and (e) and para. 2). ${ }^{48}$

In terms of the refusal of enforcement, the 2016 Proposal envisages a special rule entailing the possibility of refusal due to the change of circumstances which would make the direct enforcement manifestly contrary

1996 on Jurisdiction, Applicable Law, Recognition, Enforcement and Co-operation in Respect of Parental Responsibility and Measures for the Protection of Children or the European Convention on Recognition and Enforcement of Decisions concerning Custody of Children and on Restoration of Custody of Children (1980)) or, as the last solution, the national rules on the recognition and enforcement in force in the third State.

${ }^{45}$ The Brussels IIa Regulation if the first instrument of the EU which has abolished recognition in civil matters in respect of certified judgments on access rights to children and certified return orders in child abduction cases. See for details European Commission, 2014, pp. 9-10.

${ }^{46}$ According to the CJEU, only the courts of origin of the decision on the rights of custody in cases of child abduction are entitled to examine the suspension or refusal of a certified "privileged" decision even if the subsequent change of circumstances in the enforcement proceeding could be highly detrimental to the best interest of the child. See Povse v Alpago, paragraphs 73-74 and 80-83. Similar, the ECtHR case Povse v Austria (application no. 3890/11), paragraphs 81-82.

${ }^{47}$ CJEU Case C-491/10 Zarraga v Pelz, (2010) ECR I-14247, especially paragraphs 58-75.

${ }^{48}$ For critics on the lack of lis pendens rule when the proceeding on parental responsibility is initiated in a third State, see European Commission, 2014, p. 9. 
to the public policy of the State of enforcement. Moreover, in this case, the content of the public policy is a priori narrowed to the best interest of the child, embodied in the objection of the child who attains sufficient age and maturity. In addition, the change of circumstances which have occurred after the decision was given could also lead to the stay or refusal of enforcement if it would be manifestly incompatible with the best interests of the child (the 2016 Proposal, Art. 40 para. 2(a) and (b). The conclusion that the refusal of the enforcement is allowed even in the case of "privileged" decisions is supported by the wording of Art. 40 para. 1 of the 2016 Proposal which expressly prohibits the possibility to refuse the enforcement of the "privileged" decisions based on the grounds of non-recognition, except for the irreconcilability with the later decision. Argumentum a contrario, as the "privileged" decisions have not been explicitly excluded from the scope of Art. 40 para. 2 regulating the refusal of enforcement based on the subsequent change of circumstances which could endanger the best interest of the child, this provision seems equally applicable to the "privileged" decisions. ${ }^{49}$ In addition, the 2016 Proposal in a clear manner discerns the recognition of the "privileged" decisions, ${ }^{50}$ on the one hand, and the enforcement, on the other hand. ${ }^{51}$

\section{The 2018 General Approach - General Rule and Exceptional Cases}

The Presidency, in its 2018 General Approach, also envisages the irreconcilability as the only ground for refusal of recognition of the "privileged" decisions (Art. 47b para. 1).

Concerning the enforcement of the "privileged" decisions, the 2018 General Approach allows the authority competent for enforcement or the competent court in the Member State of enforcement to suspend, in whole or in part, the enforcement proceedings based on irreconcilability with the later decision (Art. 36/47k, para. 2(c)).

In regard to the exceptional cases, the 2018 General Approach alters the abovementioned provisions of the 2016 Proposal. Namely, the

\footnotetext{
${ }^{49}$ In the Povse case, the CJEU took the position that the enforcement of the return order cannot be refused even if the change of the circumstances after the decision was rendered could constitute serious risk to the best interest of the child. Povse, para. 81 . See in detail, Lazić, 2016, 161-183. However, one may doubt whether the overriding rule is aimed at protecting the privileged nature of the decisions or the best interest of the child. If this type of the decisions is regarded as „privileged”, it could be designated as such only to the extent where their enforcement strives to protect the best interest of the child. In exceptional cases, irrespective of the reason for the changed circumstances, insisting on the enforcement may lead to the re-victimisation of the child (if the wrongful removal or retention is seen as the first victimisation).

${ }^{50}$ The 2016 Proposal - Section 3, Subsection 1 Refusal of recognition.

${ }^{51}$ The 2016 Proposal - Section 3, Subsection 2, Refusal of enforcement.
} 
2018 General Approach deals with the significant change of circumstances in a different way. Thus, the enforcement proceedings could be suspend in exceptional cases if it would "expose the child to a grave risk of physical or psychological harm due to temporary impediments which have arisen after the decision was given, or by virtue of any other significant change of circumstances" (Art. 36/47k, para. 4). Depending on the nature of the circumstances, the suspension could be temporary, or it may lead to the refusal of the enforcement where the grave risk exception is of lasting nature (Art. 36/47k, paras. 4 and 6). Before refusing enforcement, the authority competent for enforcement or the competent court shall take any appropriate steps to facilitate enforcement in accordance with the national law and procedure and the best interests of the child (Art. 36/47k, para. 5).

By intervening in the provision of the 2016 Proposal regarding the refusal of the enforcement due to the exceptional changes of circumstances, the Presidency has revived the legal standard of the grave risk exception (physical or psychological harm) by using almost the same wording of the 1980 Hague Convention (except for "other intolerable situation", which is used only in the Convention).

Moreover, the Presidency has proposed an additional recital aimed at interpreting this provision. In that respect, one of the examples of the grave risk impediments concerns the "manifest objection of the child voiced only after the decision was given which is so strong that, if disregarded, it would amount to a grave risk of physical or psychological harm for the child" ${ }^{52}$ It is important to emphasize two facets regarding these solutions. The first one concerns the decision on the merits following a refusal to return the child under grave risk exception or the views of the child (which are privileged under the 2018 General Approach) ${ }^{53}$ The second one tackles the issue whether the refusal or the stay of the enforcement could be justified when the exceptional circumstances have occurred before the decision on the merits has been rendered.

When it comes to the first facet, it should be borne in mind that neither the 2016 Proposal nor the 2018 General Approach set the timelimits for the proceeding on the substance of rights of custody following the refusal of the return of the child, the possibility of suspension or refusal of enforcement should be kept opened for the "privileged" decisions. ${ }^{54}$ The

\footnotetext{
52 The EU Presidency, 2018, ft. 55.

${ }^{53}$ It seems that the possibility of refusal or stay of the enforcement is also applicable in the case of "privileged" decisions (though, the 2018 General Approach is not clear enough on this issue). The question is even more important since this ground goes beyond the irreconcilability which is expressly prescribed as the only ground for the refusal of enforcement (and recognition) in the 2018 General Approach. Therefore, the application of the provision of the 2018 General Approach should be clear.

${ }^{54}$ The 2018 General Approach, Art. 36/47k paras. 4-6.
} 
possibility of refusal due to the change of circumstances which make that the enforcement collide with the best interest of the child principle is justified when no time-limits have been envisaged for rendering the final "privileged" decision. Let us not forget that during the proceeding on the substance of rights of custody the child continues to live in the State of refuge, possibly with his/her mother (which appears to be the dominant profile of the abducting-parent not only in the EU but also worldwide) ${ }^{55}$ The proceeding on the substance of rights of custody could last long enough for the "exceptional" change of circumstances to occur, leading to the refusal of enforcement. However, one could question whether this subsequent change of circumstances could be considered as "exceptional" at all when there is a lack of time-limits for the proceeding on the substance of rights of custody. Is it rather the foreseeable consequence of the timeconsuming proceeding on the rights of custody?

The second facet could perhaps also open a discussion on whether the refusal of enforcement could be justified when the circumstances already existed before the "privileged" decision has been rendered. For example, it could happen that the objection of the child was raised during the proceeding on the return. However, since the case involved the child of a young age (e.g. 5 years old), ${ }^{56}$ the court refused the return of the child specifying in its decision only the grave risk exception as the ground for the refusal. ${ }^{57}$ The court in the State of the child's habitual residence has decided on the rights of custody ordering the return of the child, considering that the objection is still not serious enough and that it could be eventually overcome with the support of psychologist and social worker. As the courts keep the discretionary powers to access the weight of the child's view in accordance to his/her age and maturity, in the case of the younger children, they usually do not give

\footnotetext{
${ }^{55}$ In the EU, mother was the abducting parent in $83 \%$ of the cases. A non-return order is more likely to be issued in cases where mother is the abducting parent. Beaumont et al., 2016, p. 215-216.

${ }^{56}$ The research in the EU has showed that in $42 \%$ of the cases where the age of the child was identifiable, the children were 5 years old or younger; in some cases, the child was regarded as not having the necessary age or maturity to be heard. It was also stated that the children aged between 6 and 15 have the requisite age and maturity. However, giving the child the opportunity to be heard does not mean that their view has to be abided by, as the courts have the discretion to decide on the weight they would give to the views of the child. Beaumont et al., 2016, pp. 236-238.

${ }^{57}$ This could happen in cases of domestic violence, when the direct victim is the abducting-parent and not the child. The court in the State of refuge could find that the victim would not be protected enough with the available protection measures (e.g. that the violence occurs in patterns that make the restriction order not effective enough, while the stay of the victim and the child in the Emergency shelter/Safe house is inconvenient for the child). Therefore, the court refused the return because the separation of the pre-schooled child from his/her primary caregiver would exposed the child to psychological harm. See Permanent Bureau, 2019, p. 23 (ft. 74).
} 
significant weight to their views. ${ }^{58}$ However, the passage of time can influence the child's view and it could gradually become more serious, so that in the enforcement proceeding the child objects in such way that the decision cannot be enforced unless the coercive measures are used ${ }^{59}$ But, this case does not involve the "exceptional change of circumstances" as envisaged in the 2016 Proposal or the 2018 General Approach. ${ }^{60}$ Again, one may not argue that the passage of time could be subsumed under the "exceptional change of circumstances" if there are no time-limits for the proceedings on the substance of rights of custody. On the contrary, with no time-limits set, the passage of time and its impact on the child's view could be indisputable. ${ }^{61}$ In these circumstances, one could question whether the fact that the court has underestimated the gradual influence of passage of time to the child's view could excuse the use of coercive measures when the child objects the return in the enforcement proceeding (in a serious manner), ${ }^{62}$ although he/she already objected during the proceeding on the merits (but in the less serious manner) ${ }^{63}$ In other words, should the free movement of judgments (as the most visible aspect of the mutual trust principle) prevail over the protection of the best interest of the child, ${ }^{64}$ which has to be taken into consideration in

\footnotetext{
${ }^{58}$ This argument also leans on the survey done in the EU States which shows that the views of children under the age of 6 did not influence the outcome of the return proceeding, if the child was heard at all. Beaumont et al., 2016, pp. 233, 236-238. Despite the fact that the 2016 Proposal and the 2018 General Approach in the same articles (Arts. 20 and 24) envisage that the court shall ensure that a child who is capable of forming his or her own views is given the genuine and effective opportunity to express those views freely during the proceedings, the courts keep the discretionary powers to evaluate the significance of the child's view. Practically, the hypothetical example given in this paper could happen in reality.

${ }^{59}$ On the admissibility of the coercive measures towards children, see the ECtHR decision in Raw v France, paragraph 80. Also McEleavy, 2005, p. 33.

${ }^{60}$ One of the latest ECtHR decisions in this matter illustrates how the passage of time gradually influences the child's view. See: M.K. v Greece of 1st February 2018 (application 51312/16) and comments on this controversial judgement in Lembrechts, 2019, https://strasbourgobservers.com/2018/03/22/m-k-v-greece-implementing-childrensrights-in-legal-proceedings-following-an-international-parental-abduction/.

${ }^{61}$ See ft. 60. Moreover, in one of the most famous cases, Maumousseau and Washington v. France, the ECtHR has stated that "proceedings relating to the award of parental responsibility, including the enforcement of the final decision, require urgent handling as the passage of time can have irremediable consequences for relations between the child and the parent with whom it does not live". Maumousseau and Washington v. France 39388/05 Judgment 6.12.2007 [Section III], para. 83.

${ }^{62}$ The ECtHR has stated that in this sensitive area, the use of coersive measures against children are not desirable. Maumousseau and Washington v. France 39388/05 Judgment 6.12.2007 [Section III], para. 83 .

${ }^{63}$ The 2018 General Approach does not exclude the use of coercive measures. Presidency, 2018, p. 75 (recital 53).

${ }^{64}$ Lenaerts, 2013, pp. 1305, 1316. Walker, Beaumont, 2011, pp. 231-249.
} 
every proceeding involving the child ${ }^{65}$ including the enforcement? As Lenaerts point out, the CJEU does not give absolute priority to the mobility of judgments over the protection of fundamental rights. ${ }^{66}$ Hence, more flexible approach which would allow the stay or refusal of enforcement even when the "exceptional circumstances" occurred before the decision was given could be taken into consideration for the "privileged" decisions. Otherwise, if the application of the exceptional circumstances is limited only to the cases when they have occurred after the decision was given, it only leads to the conclusion that there is hidden lack of trust with the State of enforcement whose courts are not authorized to order the stay or refuse the enforcement when the change of circumstances has occurred before the decision was given. ${ }^{67}$ On the one hand, there is a presumption that nothing can go wrong in the proceeding on the substance of the rights of custody, even in case of a time-consuming dispute. On the other hand, there seems to be a degree of distrust in the court of enforcement, which is based on the assumption that the court will automatically allow the stay or refusal of enforcement without duly appraising the intensity of the changed circumstances.

The principle of mutual trust should indeed be mutual. Therefore, if the Brussels IIa Recast remains silent on the issue of time-limits for the proceedings on the substance of the rights of custody, then the possibility to stay or to refuse the enforcement should be kept open even for the second situation, which is not regulated by the Commission's Proposal nor by the 2018 General Approach. It concerns the case where the circumstances have gradually changed before the decision on the merits was rendered but the court has underestimated the seriousness of the growing influence of passage of time. Thus, the court has roughly assessed that the change of circumstances is not yet serious enough and that it could be overcome. However, if they cannot be overcome, it is a hands tied situation since the court of enforcement lacks the power to order the stay or refusal of the enforcement. Therefore, it seems that the wording of Article 36/47k para. 4 of the 2018 General Approach should be altered as follows: “... if enforcement would expose the child to a grave risk of physical or psychological harm due to any significant change of circumstances which cannot be reasonalby overcome... ".

\footnotetext{
${ }^{65}$ Art. 3 para 1 of the Convention on the Rights of the Child; Art. 24(1) of the Charter of Fundamental Rights of the European Union.

${ }^{66}$ Lenaerts, 2013, p. 1305.

${ }^{67}$ The overriding rule was described by some scholars as the procedure which „flies in the face of mutual trust". Kruger et al., 2016, 158. Besides, the 2016 Proposal and the 2018 General Approach do not envisages any restrictions on the type or the number of the legal remedies allowed in the proceeding on the substance of the rights of custody. Hence, it is unclear whether the change of circumstance should occur after the first instance decision was rendered or after the decision on the appeal or the decision on the extraordinary legal recourse.
} 


\section{CONCLUSION}

The 2016 Proposal and the 2018 General Approach introduce important novelties in terms of international child abduction and subsequent proceedings on the substance (merits) of rights of custody. However, there is still room for further improvements, especially bearing in mind that these two documents propose different solutions for some important issues (the number of appeals and concentration of local jurisdiction in the return proceeding, grounds for the refusal of the child's return which sets in motion the overriding mechanism). Regardless of which approach will be accepted in the final version of the Brussels IIa recast, the 2016 Proposal and the 2018 General Approach share two major common problems. As we have seen, neither of these documents imposes the time-limits for deciding on the substance of rights of custody when the return of the child is refused on the specific ground leading to the overriding mechanism. The silence on this topic challenges basic principles regarding the return of the child: the principle of urgency, the principle of mutual trust, and the principle of the child's best interest. Although the outcome of the proceeding on the substance of rights of custody cannot be anticipated, it could result in the privileged decision entailing the return of the child. Without imposing any reasonable time-limits for deciding in this type of proceedings, the final consequence could jeopardize the principle of the urgent return of the child and the best interest of the child. Since the overriding rule gives the primacy to the privileged decision over the decision of non-return, insisting on the precise time-limits only for the return proceeding in order to keep in line with the principle of urgency, while remaining silent on the same issue for the subsequent proceeding on the substance of rights of custody, is inconsistent with the general aim of the future Brussels IIa recast to improve efficiency of the overriding rule. This lack of time-limits could lead to the problem of the stay/refusal of direct enforcement of the privileged decisions issue. Bearing in mind that the 2016 Proposal (explicitly) and the 2018 General Approach (less explicitly) allow the stay/refusal of direct enforcement of the privileged decisions in exceptional cases, the lack of time-limits for the proceeding on the merits could bring into question the justification of this rigid solution in certain cases. If there are no time-limits for the subsequent proceeding on the substance of rights of custody, could the raise of serious objection of the child in the enforcement proceeding be prevented or even considered as an exceptional case, or should it be seen as a possible consequence of the lack of time-limits and the passage of time? Consequently, the provision on the stay/refusal of enforcement of the privileged decision should be more flexible. Otherwise, it would be a clear sign that there is almost a complete lack of trust with the judicial system of the State of enforcement (State of refuge). The arbitrariness of this approach comes to the fore even more when that State is the State of child's habitual residence. Then, the trust with the judicial system of that same State is 
almost unlimited. One should keep in mind that the idea underlying the mutual trust principle is actually the trust in the judicial system of the Member States. In other words, a better balance between the principle of urgency, the mutual trust principle and the best interest of the child principle calls either for imposing the reasonable time-limits for the subsequent proceeding on the substance of rights of custody or for vesting more trust in the judicial system of the State of enforcement by providing reasonably flexible solutions for the stay/refusal of the privileged decisions. Therefore, the dilemma whether the significant change of circumstances should occur before or after the decision was given in order to justify the stay or refusal of enforcement is less important than the possibility to enforce the decision on the merits by adhering to the best interest of the child.

\section{REFERENCES}

Beaumont, P., Walker, L., Holliday, J. (2016). Conflict of EU courts on child abduction: the reality of Article 11(6)-(8) Brussels IIa proceedings across the EU. Journal of Private International Law, 12(2), 211-260. doi: 10.1080/17441048.2016.1206708.

Case C-211/10 PPU (Povse v. Alpago) (2010] ECR I-6669.

Case C-491/10 Zarraga v Pelz, (2010) ECR I-14247.

Convention of 25 October 1980 on the Civil Aspects of International Child Abduction. Official Gazette of the SFRY- International Treaties. No. 7 (1991).

Convention on the Rights of the Child, Official Gazette of the SFRY - International Treaties. No.15 (1990) and Official Gazette of SRY - International Treaties. No. 4 (1996) and 2(1997).

Convention on Recognition and Enforcement of Decisions concerning Custody of Children and on Restoration of Custody of Children, Official Gazette of SRY. No. $1 / 2001$.

Convention of 19 October 1996 on Jurisdiction, Applicable Law, Recognition, Enforcement and Co-operation in Respect of Parental Responsibility and Measures for the Protection of Children, Official Gazette of RS - International Treaties. No. 20/2015.

Council Regulation (EC) No 2201/2003 of 27 November 2003 concerning jurisdiction and the recognition and enforcement of judgments in matrimonial matters and the matters of parental responsibility, repealing Regulation (EC) No 1347/2000, OJ L. 338(23.12.2003).

Council of the EU. Council agrees on more effective rules to solve cross border parental responsibility issues. 2018. Retrieved from https://www.consilium.europa.eu/en/ press/press-releases/2018/12/07/council-agrees-on-more-effective-rules-to-solvecross-border-parental-responsibility-issues/pdf.

Charter of Fundamental Rights of the European Union, OJ C. 326 (26.10.2012).

Drventić, M. (2017). New Trends in European Family Procedural Law. In: Duić, D., Petrašević, T. (Eds): Jean Monnet International Scientific Conference, EU and Comparative Law Issues and Challenges Series, Procedural Aspects of EU Law (424-446). Osijek: Faculty of Law Josip Juraj Strossmayer University of Osijek.

Dutta, A. (2016). Cross-border protection measures in the European Union. Journal of Private International Law, 12(1), 169-184. doi: 10.1080/17441048.2016.1143689. 
Dutta, A., Schulz, A. (2014). First Cornerstones of the EU Rules on Cross-border Child Cases: the Jurisprudence of the Court of Justice of the European Union on the Brussels IIa Regulation from $C$ to Health Service Executive. Journal of Private International Law, 10(1), 1-40. doi:10.5235/17441048.10.1.

European Commission. Proposal for a Council Regulation on jurisdiction, the recognition and enforcement of decisions in matrimonial matters and the matters of parental responsibility, and on international child abduction (recast), COM(2016) 411 final 2016/0190 (CNS). 30.6.2016. Retrieved from https://ec.europa.eu/transparency/ regdoc/rep/1/2016/EN/1-2016-411-EN-F1-1.PDF.

European Commission. Report from the European Commission to the European Parliament, the Council and the European Economic and Social Committee on the application of Council Regulation (Ec) No 2201/2003 concerning jurisdiction and the recognition and enforcement of judgements in matrimonial matters and the matters of parental responsibility, repealing Regulation (EC) No 1347/2000. COM (2014) 225 final. 15.4.2014. Retrieved from https://publications.europa.eu/en/ publication-detail/-/publication/f09ad6d9-c494-11e3-9fe4-01aa75ed71a1/language -en.

European Commission. Practice Guide for the Application of the Brussels IIa Regulation. 2014. Retrieved from https://publications.europa.eu/en/publication-detail//publication/f7d39509-3f10-4ae2-b993-53ac6b9f93ed.

EU Presidency. Proposal for a Council Regulation on jurisdiction, the recognition and enforcement of decisions in matrimonial matters and the matters of parental responsibility, and on international child abduction (recast) - General approach. 30 November 2018. Retrieved from http://data.consilium.europa.eu/doc/document/ ST-14784-2018-INIT/en/pdf.

Kruger, Th., Samyn, L. (2016). Brussels II bis: successes and suggested improvements. Journal of Private International Law. 12(1), 132-168. doi:10.1080/17441048. 2016.1151150.

Lazić, V. (2016).'Family Private International Law Issues before the European Court of Human Rights - Lessons to be Learned from Povse v. Austria in Revising the Brussels IIa Regulation and its Relevance for Future Abolition of Exequatur in the European Union. In: Ch. Paulussen, T. Takacs, V. Lazić, B. Rompuy (Eds.), Fundamental Rights in International and European Law - Public and Private Law Perspectives (161-185). The Hague: Asser Press/Springer. doi: 10.1007/978-946265-088-6_8.

Lazić, V. (ed.). (2018). Recommendations To Improve the Rules on Jurisdiction and on the Enforcement of Decisions in Matrimonial Matters and Matters of Parental Responsibility in the European Union. Retrieved from https://www.asser.nl/media/ 4662/m-5796-ec-justice-cross-border-proceedings-in-family-law-matters-10publications-00-publications-on-asser website-recommendations.pdf.

Lazić, V. (ed.). (2018). Brussels IIbis: Guide for Application. Retrieved from https://www. asser.nl/media/5260/cross-border-proceedings-guide-for-application.pdf.

Lembrechts, S. (2019). M.K. v. Greece - Implementing children's rights in legal proceedings following an international parental abduction. Retrieved from https://strasbourgobservers.com/2018/03/22/m-k-v-greece-implementingchildrens-rights-in-legal-proceedings-following-an-international-parentalabduction/.

Lenaerts, K. (2013). The best interest of the child always come first: the Brussels II bis Regulation and the European Court of Justice. Jurisprudence, 20(4), 1302-1328. doi:10.13165/JUR-13-20-4-02. 
Marjanović, S. (2015). Zaštita dece u haškim konvencijama o međunarodnom privatnom pravu: doktorska disertacija (Children Protection in the Hague Conventions on Private International Law: $\mathrm{PhD}$ thesis). Niš: Sven.

Maumousseau and Washington v. France 39388/05 Judgment 6.12.2007 [Section III].

McEleavy, P. (2015). The European Court of Human Rights and the Hague Child Abduction Convention: Prioritising Return or Reflection? Netherland International Law Review, 62, 365-405. doi: 0.1007/s40802-015-0040-z.

McEleavy, P. (2005). The New Child Abduction Regime in the European Community: Symbiotic Relationship or Forced Partnership. Journal of Private International Law, 1(1), 5-34. doi: 10.1080/17536235.2005.11424287.

M.K. v Greece of 1st February 2018 (application 51312/16).

Nyts, A., 2007 Report Study on Residual Jurisdiction, available at http://ec.europa. eu/justice_home/doc_centre/civil/studies/doc_civil_studies_en.htm.

Permanent Bureau of the Hague Conference on Private International Law. Revised draft Guide to Good Practice on Article 13(1)(b) of the 1980 Convention. March 2019. Retrieved from https://assets.hcch.net/docs/1e6f828a-4120-47b7-83aca11852f77128.pdf.

Permanent Bureau of the Hague Conference on Private International Law. Statistical analysis of applications made in 2008 under the Hague Convention of 25 October 1980 on the Civil Aspects of International Child Abduction - Part II - Regional Report. Prel. Doc. No 8 B - update of November 2011 for the attention of the Special Commission of June 2011. 2011. Retrieved from https://assets.hcch.net/ upload/wop/abduct2011pd08be.pdf.

Povse v Austria (application no. 3890/11).

Prechal, S. (2017). Mutual Trust Before the Court of Justice of the European Union. European Papers, 2, No. 1, 75-92. doi: 10.15166/2499-8249/139.

Raw $v$ France (application no. 10131/11).

Shaw $v$ Hungary (application no. 6457/09).

Ubertazzi, B. (2017). The hearing of the child in the Brussels IIa Regulation and its Recast Proposal. Journal of Private International Law, 13(3), 568-601. doi:10.1080/ 17441048.2017.1386262.

Walker, L., Beaumont, P. (2011). Shifting the Balance Achieved by the Abduction Convention: The Contrasting Approaches of the European Court of Human Rights and the European Court of Justice. Journal of Private International Law, 7(2), 231249. doi: $10.5235 / 174410411796868689$.

Šneersone and Kampanella $v$ Italy (application No 14737/09).

Župan, M., Poretti, P. (2015). Concentration of jurisdiction in cross-border family matters child abduction at focus. In: Vinković, M. (Ed.): Jean Monnet Conference, New developments in EU labour, equality and human rights law (pp. 341-359). Osijek: Faculty of Law Josip Juraj Strossmayer University of Osijek. 


\title{
ПРЕДЛОГ ИЗМЕНА УРЕДБЕ БРИСЕЛ На: НЕДОСТАЦИ ТЗВ. ПРЕОВЛАЪУЈУЋЕГ ПРАВИЛА
}

\author{
Сања Марјановић \\ Универзитет у Нишу, Правни факултет, Ниш, Србија
}

\section{Резиме}

Иако и Предлог из 2016. године за измену Уредбе Брисел ПІа и Општи приступ из 2018. године доносе значајна унапређења досадашњих решења, два главна недостатка морају бити узета у обзир будући да су међусобно повезана. Први се тиче недостатка рокова у погледу мериторног одлучивања о праву на старање, када је поступак покренут након одбијања повратка детета на основу „преовлађујућег правила". Имајући у виду да и Предлог и Општи приступ предвиђају стриктне рокове за одлучивање о повратку детета, истовремени недостатак било каквих разумних рокова за окончање поступка у коме се може донети „привилегована” одлука (о садржини права на старање) чини се контрадикторним принципу међусобног поверења и најбољег интереса детета. Други камен спотицања односи се на могућност застајања са поступком извршења ове врсте одлука или одбијање извршења услед изузетних околности, поводом које постоје разлике између одредаба Предлога (2016) и оних из Општег приступа (2018). У појединим случајевима, може се чак поставити и питање да ли недостатак рокова за доношење „привилеговане” одлуке може оправдати одбијање извршења у околностима које не би биле изузетне. С тим у вези, чини се да су могућа два решења. Једно од њих подразумева увођење рокова за одлучивање о садржини права на старање које може резултирати и „привилегованом" одлуком. Уколико наведени рокови не буду предвиђени, други излаз из ове ситуације могао би се пронаћи у додатним изменама предложених одредаба о одбијању извршења у циљу њихове флексибилизације, које би довеле до тога да, барем поводом извршења „привилегованих” одлука, превагне принцип најбољег интереса детета над принципом међусобног поверења. У супротном, ако ни Брисел Па recast не интервенише у погледу рокова за мериторно одлучивање или, алтернативно, у погледу флексибилности одредаба о застајању/одбијању непосредног извршења, онда неће бити превазиђени скривени, али озбиљни недостатак поверења у судски систем државе извршења. То је контрадикторно пуном поверењу које се поклања судком систему те исте државе ако се у њој налази уобичајено боравиште детета. Ова контрадикторност је очигледна и у важећем Брисел ІІа режиму, као и у Предлогу за измене (2016) и Општем приступу (2018). 